\title{
NONLINEAR MONOTONIZATION OF THE BABENKO SCHEME ${ }^{1}$
}

\author{
M.P. GALANIN and T.G. YELENINA \\ Keldysh Institute of Applied Mathematics of $R A S$ \\ Miusskaya Sq. 4, Moscow A-47, 125047, Russia \\ E-mail: galan@keldysh.ru; elen@keldysh.ru
}

Received October 15, 2002; revised February 25, 2003

\begin{abstract}
The goal of the paper is to present and test the nonlinear monotonization of the Babenko scheme for solving 2D linear advection equation with alternating-sign velocities. The numerical method of monotonization is based on the idea of limited artificial diffusion.

There are some approaches for constructing quasi-monotonic second order approximation schemes for solving hyperbolic systems and equations of gas dynamics: flux correction methods, the Godunov method, TVD methods and others. In particular, many authors developed the idea of TVD method. We try to use this idea to get a new quasi-monotonic high order accuracy scheme based on the well-known non-monotonic Babenko scheme. The algorithm is presented for $1 \mathrm{D}$ problem. For testing 2D problem we use the splitting algorithm. The proposed monotonized scheme has shown the best results among all considered in the paper schemes especially for non-smooth initial profile.
\end{abstract}

Key words: Babenko scheme, TVD method, high order accuracy scheme, monotonized scheme

\section{STATEMENT OF THE PROBLEM}

Let us consider an initial value problem for the two-dimensional advection equation

$$
\frac{\partial \rho}{\partial t}+\frac{\partial}{\partial x}\left(\rho v_{1}\right)+\frac{\partial}{\partial y}\left(\rho v_{2}\right)=0
$$

\footnotetext{
${ }^{1}$ The work was partially supported by Russian Foundation for Basic Research (RFBR) (projects 00-01-00169, 02-01-06583) and INTAS 00-491
} 

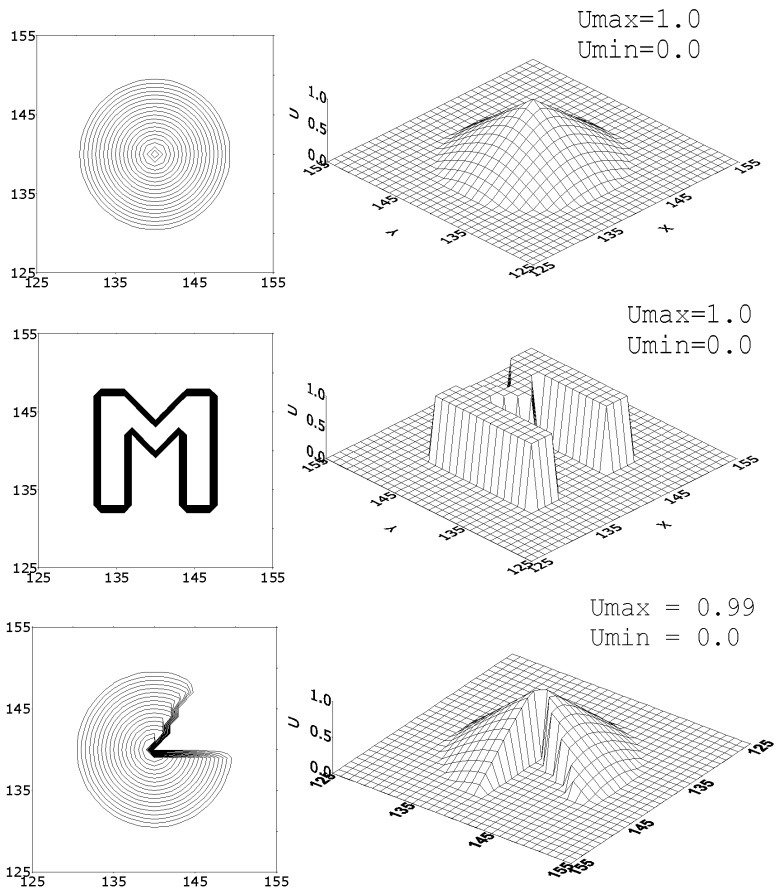

Figure 1. The typical initial profiles $\rho_{0}(x, y)$ for testing numerical methods.

with alternating-sign velocities $v_{1}=v_{1}(x, y, t), v_{2}=v_{2}(x, y, t)$ in a space-time domain $(x, y) \in R^{2}, t>0$. The following initial data (see Fig.1) is also given:

$$
\rho(x, y, 0)=\rho_{0}(x, y)= \begin{cases}R(r, \varphi), & 0 \leqslant r \leqslant r_{0} \\ 0, & r_{0}<r\end{cases}
$$

where

$$
\begin{aligned}
& r=\sqrt{\left(x-x_{00}\right)^{2}+\left(y-y_{00}\right)^{2}}, \\
& \varphi= \begin{cases}\arccos \left(\left(x-x_{00}\right) / r\right), & y \geqslant y_{00}, \\
2 \pi-\arccos \left(\left(x-x_{00}\right) / r\right), & y<y_{00},\end{cases} \\
& r_{0}=\text { const }>0, \quad x_{00}=\text { const }, y_{00}=\text { const } .
\end{aligned}
$$

The main goal of the paper is to develope a new quasi-monotonic high order accuracy finite-difference scheme and test it by comparing with a representative set of well-known schemes. The numerical method of monotonization is based on the idea of introduction a limited artificial diffusion which ensures the monotonization. The application of the proposed limiters to the diffusion led to the high accuracy [3]. Such method of the construction was offered by Osher, Chacravarthy [5] and was developed in papers of Favorskii, 


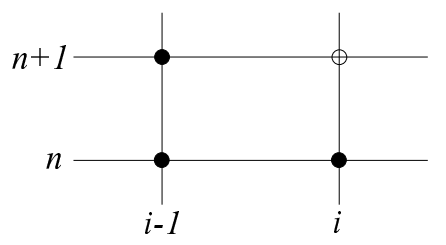

Figure 2. The grid stencil for the basic scheme.

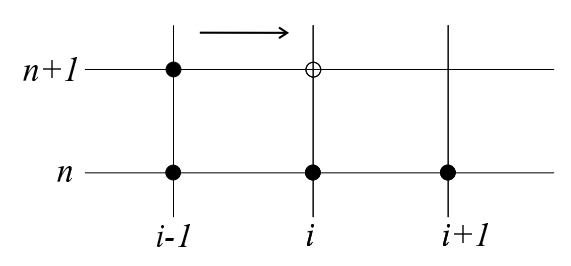

Figure 3. Grid stencil for the case 1.

Tishkin, Vyaznikov [7] and others [2]. This approach has been applied to the well-known non-monotonic Babenko scheme [1], also known as "square" scheme. As a result the new quasi-monotonic non-linear scheme has been constructed [4]. The comparative analysis has demonstrated the high quality of this scheme. We use the splitting algorithm [6] for solving 2D problem. Below we present the monotonization algorithm for 1D problem.

\section{NEW SCHEME}

In order to solve the problem numerically first let us consider the basic Babenko non-monotonic scheme ("square"). It is given by the following equation

$$
u_{i}^{n+1}=u_{i-1}^{n} \frac{1+\gamma_{i-1}}{1+\gamma_{i}}-\frac{1-\gamma_{i-1}}{1+\gamma_{i}}\left(u_{i-1}^{n+1}-u_{i}^{n}\right),
$$

where $\gamma_{i}=v_{1}\left(x_{i}, t\right) \tau / h, \tau, h$ are discrete steps. A stencil of this scheme is given in Fig.2.

Then we introduce an artificial diffusion in some way. The magnitude of a coefficient of artificial diffusion depends on a solution. We choose this coefficient to be such that the scheme satisfies monotonicity conditions [6]. Below in Fig.4 one can see the difference between the new quasi-monotonic and the basic non-monotonic scheme for the case of one spatial dimension and constant positive velocity.

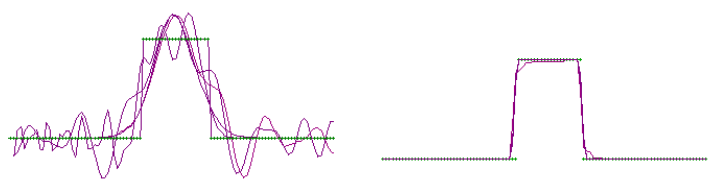

Figure 4. Final profiles (for $\mathrm{T}=400$ ) for a set of Courant numbers (1D case, $\gamma_{i}=\tau / h$ ). a) Basic nonmonotonic scheme: the Babenko scheme for $\gamma=0.1 ; 0.5 ; 1.0 ; 1.1 ; 1.5 \mathrm{~b})$ New qusimonotonic scheme for $\gamma=0.1 ; 0.25 ; 0.5 ; 0.9$

Now let us investigate this problem for the case of alternating-sign velocities. The region where the sign of the velocity is preserved contains at least 3 neighbouring points. In order to state a correct problem for hyperbolic 


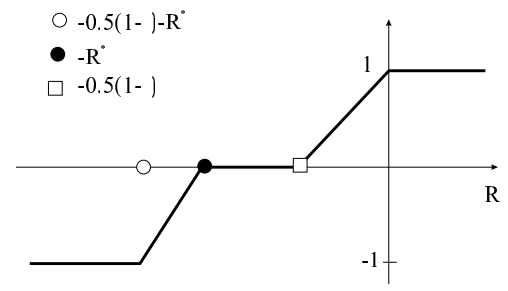

Figure 5. The dependence of artificial diffusion $\mu$ on $R$.

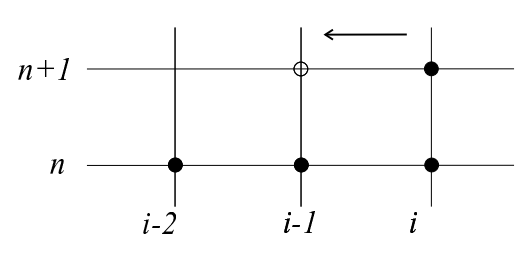

Figure 6. Grid stencil for the case 2 .

equations it is necessary to specify as many conditions as a number of characteristics which go from the boundaries into the considered region. Because of the fact that the velocity is of an alternating-sign there are four cases.

Case $1\left(\gamma_{i-1}, \gamma_{i}, \gamma_{i+1} \geqslant 0\right)$ : the characteristics turn to the right. The advection of the solution starts from the left boundary. The scheme is given as follows:

$$
\begin{aligned}
& \left(u_{i}^{n+1}-u_{i}^{n}\right)\left[\left(1+\gamma_{i}\right)+\left(1-\gamma_{i}\right) \mu\left(R_{i}^{+}, \gamma_{i}\right)\right. \\
& \quad+\left(u_{i-1}^{n+1}-u_{i-1}^{n}\right)\left(1-\gamma_{i-1}\right)\left(1-\mu\left(R_{i-1}^{+}, \gamma_{i-1}\right)\right)+2\left(\gamma_{i} u_{i}^{n}-\gamma_{i-1} u_{i-1}^{n}\right)=0
\end{aligned}
$$

where $R_{i}^{+}=\frac{\gamma_{i+1} u_{i+1}^{n}-\gamma_{i} u_{i}^{n}}{u_{i}^{n+1}-u_{i}^{n}}$ and $u_{i}^{n+1}$ is unknown quantity. It has the stencil given in Fig.3.

The limiters are defined as follows (Fig.5):

$$
\mu(R, \gamma)= \begin{cases}1, & R \geqslant 0, \\ 1+2 R /(1-\gamma), & -0.5(1-\gamma) \leqslant R<0 \\ 0, & -R^{*} \leqslant R<-0.5(1-\gamma), \\ 2\left(R+R^{*}\right) /(1-\gamma), & -R^{*}-0.5(1-\gamma) \leqslant R<-R^{*} \\ -1, & R<-R^{*}-0.5(1-\gamma) .\end{cases}
$$

Case $2\left(\gamma_{i-2}, \gamma_{i-1}, \gamma_{i} \leqslant 0\right)$ : the characteristics turn to the left. The advection of the solution starts from the right boundary. The scheme is given as follows:

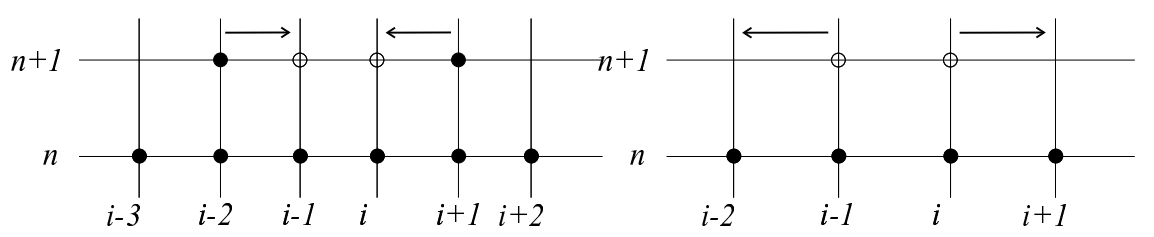

Figure 7. Grid stencil for the case 3 .

Figure 8. Grid stencil for the case 4 . 

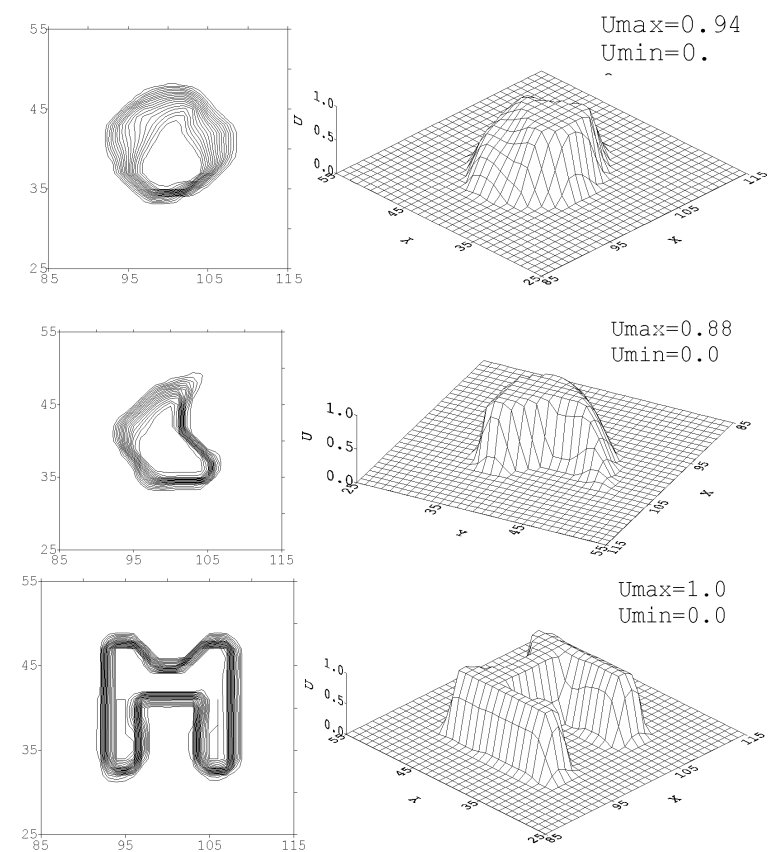

Figure 9. Results of testing of the proposed scheme for all initial profiles.

$$
\begin{aligned}
& \left(u_{i-1}^{n+1}-u_{i-1}^{n}\right)\left[\left(1-\gamma_{i-1}\right)+\left(1+\gamma_{i-1}\right) \mu\left(R_{i-1}^{-},-\gamma_{i-1}\right)\right] \\
& \quad+\left(u_{i}^{n+1}-u_{i}^{n}\right)\left(1+\gamma_{i}\right)\left(1-\mu\left(R_{i}^{-},-\gamma_{i}\right)\right)+2\left(\gamma_{i} u_{i}^{n}-\gamma_{i-1} u_{i-1}^{n}\right)=0
\end{aligned}
$$

where $R_{i}^{-}=\frac{\gamma_{i} u_{i}^{n}-\gamma_{i-1} u_{i-1}^{n}}{u_{i}^{n+1}-u_{i}^{n}}$ and $u_{i-1}^{n+1}$ is unknown quantity.

The grid stencil of the scheme is shown on Fig.6.

Case $3\left(\gamma_{i-3}, \gamma_{i-2}, \gamma_{i-1} \geqslant 0 ; \gamma_{i}, \gamma_{i+1}, \gamma_{i+2} \leqslant 0\right)$ : for these velocities the advection of the solution is comming from both boundaries into the region. The characteristics (passing through $x_{i-3}, x_{i-2}, x_{i-1}$ ) turn to the right, and the characteristics (passing through $x_{i}, x_{i+1}, x_{i+2}$ ) turn to the left. We find unknown quantities $u_{i}^{n+1}, u_{i-1}^{n+1}$ solving the system.

$$
\left\{\begin{array}{l}
\left(u_{i-1}^{n+1}-u_{i-1}^{n}\right)\left[1+0.25 \gamma_{i-1}(1-\mu(R, 0))\right]+0.25\left(u_{i}^{n+1}-u_{i}^{n}\right) \gamma_{i}(1-\mu(R, 0)) \\
\quad+0.5\left(1-\gamma_{i-2}\right)\left(1-\mu\left(R_{i-2}^{+}, \gamma_{i-2}\right)\right)\left(u_{i-2}^{n+1}-u_{i-2}^{n}\right) \\
\quad+0.5\left(\gamma_{i} u_{i}^{n}+\gamma_{i-1} u_{i-1}^{n}\right)-\gamma_{i-2} u_{i-2}^{n}=0 \\
\quad\left(u_{i}^{n+1}-u_{i}^{n}\right)\left[1-0.25 \gamma_{i}(1-\mu(R, 0)]-0.25\left(u_{i-1}^{n+1}-u_{i-1}^{n}\right) \gamma_{i-1}(1-\mu(R, 0))\right. \\
\quad+0.5\left(1+\gamma_{i+1}\right)\left(1-\mu\left(R_{i+1}^{-},-\gamma_{i+1}\right)\right)\left(u_{i+1}^{n+1}-u_{i+1}^{n}\right) \\
\quad-0.5\left(\gamma_{i} u_{i}^{n}+\gamma_{i-1} u_{i-1}^{n}\right)+\gamma_{i+1} u_{i+1}^{n}=0
\end{array}\right.
$$




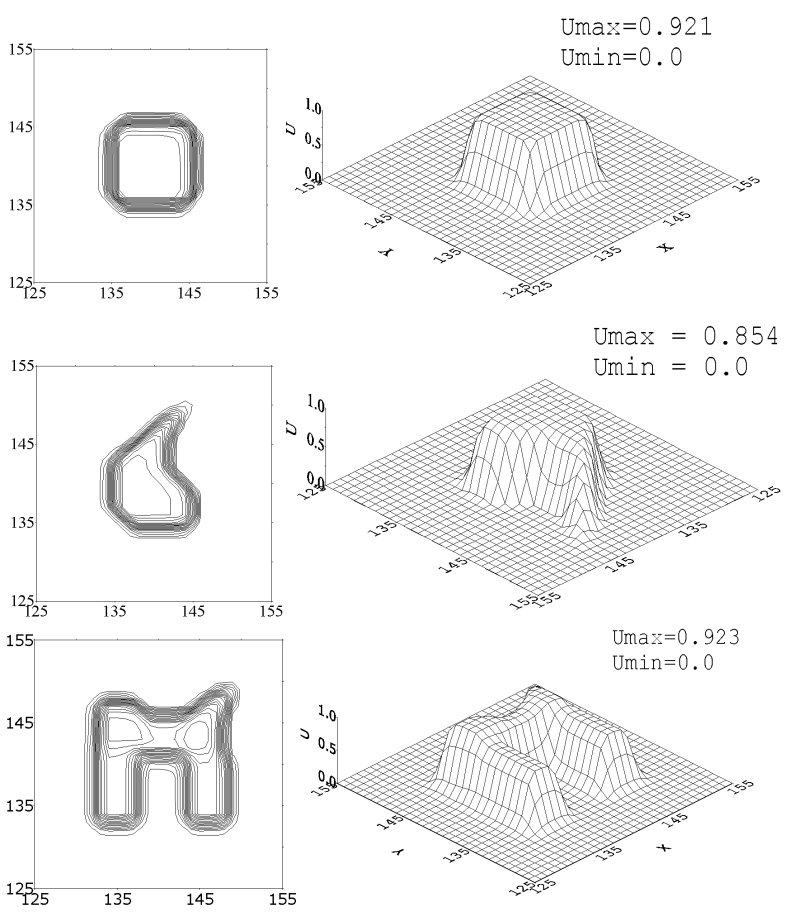

Figure 10. Results of testing "limiters" method for all initial profiles.

$R=\max \left(R_{i}^{-}, R_{i-1}^{+}\right)$. For this case we have the grid stencil given in Fig.7.

Case $4\left(\gamma_{i-3}, \gamma_{i-2}, \gamma_{i-1} \leqslant 0 ; \gamma_{i}, \gamma_{i+1}, \gamma_{i+2} \geqslant 0\right)$ : there is the advection out of the region (see Fig.8). The directions of the characteristics are opposite to those in the previous case. The scheme is given as:

$$
\left\{\begin{array}{l}
l\left(u_{i}^{n+1}-u_{i}^{n}\right)\left[\left(1+\gamma_{i}\right)+\left(1-\gamma_{i}\right) \mu\left(R_{i}^{+}, \gamma_{i}\right)\right]+2 \gamma_{i} u_{i}^{n}=0, \\
\left(u_{i-1}^{n+1}-u_{i-1}^{n}\right)\left[\left(1-\gamma_{i-1}\right)+\left(1+\gamma_{i-1}\right) \mu\left(R_{i-1}^{-},-\gamma_{i-1}\right)\right]-2 \gamma_{i-1} u_{i-1}=0 .
\end{array}\right.
$$

\section{RESULTS OF TESTING AND CONCLUSIONS}

Let us present the results of solving test problems with the new scheme (see Fig.9). The numerical solutions were obtained for all initial profiles (see Fig.1) taking $\gamma=0.25$,

$$
v_{1}(x, y)=\left\{\begin{array}{cl}
1, & 0<t \leqslant 0.25 T \\
-1, & 0.25 T<t \leqslant 0.5 T \\
-1, & 0.5 T<t \leqslant 0.75 T \\
1, & 0.75 T<t \leqslant T
\end{array}, v_{2}(x, y)=\left\{\begin{array}{cl}
1, & 0<t \leqslant 0.25 T \\
1, & 0.25 T<t \leqslant 0.5 T \\
-1, & 0.5 T<t \leqslant 0.75 T \\
-1, & 0.75 T<t \leqslant T
\end{array}\right.\right.
$$




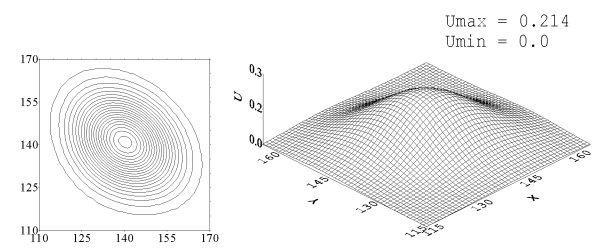

Figure 11. Result of testing the Lax method for " $M$ "-shaped initial profile.

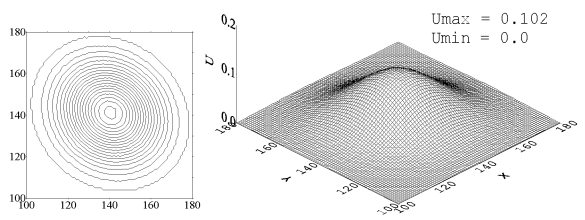

Figure 12. Result of testing of explicit upwind and downwind method for "M"-shaped initial profile.

and the final time moment is $T=480$.

The numerical solution has dissipated in few grid nodes. The shape of the third initial profile surface practically has not changed. The amplitude of the other two initial profiles has fallen slightly.

We have compared the new scheme with the following well-known finitedifference schemes: "limiters" method [7] (see Fig.10), the Lax method (see Fig.11), explicit upwind and downwind method [6] (see Fig.12).

The criterion of the comparison is a magnitude of an error of a numerical solution. The best scheme gives a minimum error value. The error analysis allows one to make the following conclusion. The proposed scheme with the monotonization has shown better results than known schemes, especially for the "M"-shaped initial profile.

\section{REFERENCES}

[1] K. I. Babenko and G. P. Voskresenskii. Numerical method for calculation of a spatial flow over a body by the supersonic gas thoughput. J. of Comput. Math. and Math. Phys., 1(6), 1051, 1961.

[2] J. P. Boris and D. L. Book. Flux corrected transport, I, SHASTA. J. Comp. Phys., 11, 1973.

[3] M. P. Galanin and T. G. Yelenina. The nonlinear monotonization of difference schemes for linear advection equation. Preprint of Keldysh Inst. of Appl. Math. of RAS, 44, 1999.

[4] M. P. Galanin and T. G. Yelenina. Nonlinear monotonization of babenko schemes for linear advection equation. Preprint of Keldysh Inst. of Appl. Math. of RAS, 4, 2002.

[5] S. Osher and S. Chakravarthy. High resolution schemes and the entropy conditions. SIAM J. Numer. Anal., 21(5), 1984.

[6] A. A. Samarsky. The theory of finite difference schemes. Nauka, Moskva, 1977. 
[7] K. V. Vyaznikov, V. F. Tishkin and A. P. Favorskii. Construction of monotonic high order difference schemes for approximation of hyperbolic type equations system. Math. Model., 1(5), 95 - 120, 1989.

\section{Babenko schemos ("kvadrato") netiesinè monotonizacija}

M.P. Galanin, T.G. Yelenina

Straipsnio tikslas yra Babenko schemos dvimačiam tiesiniam advekcijos uždaviniui su ženklą keičiančiais greičiais netiesinès monotonizacijos metodo pateikimas ir testavimas. Skaitinis monotonizacijos metodas remiasi dirbtinès difuzijos ivedimo idejja. Egzistuoja keli kvazimonotoniniu antros aproksimacijos eilès schemų hiperbolinèms sistemoms ir dujų dinamikos lygtims konstravimo būdai: srautų korekcijos metodas, Godunovo metodas, TVD ir kiti metodai. Mes naudojame TVD idejją naujos kvazimonotoninès aukštos tikslumo eilès schemos gavimui remiantis plačiai žinoma monotonine baigtiniu skirtumu Babenko schema. Skaitinis algoritmas pateiktas vienmačio uždavinio atveju. Dvimačio uždavinio sprendimui taikomas faktorizacijos algoritmas. Pasiūlytos monotonizuotos schemos pagalba gauti rezultatai yra geriausi, lyginant su kitų straipsnyje naudojamų schemų skaičiavimų rezultatais. Ypatingai gerai tai matoma neglodaus pradinio profilio atveju. 